\title{
Multiple Forms of Alanine Aminopeptidase, Alkaline Phosphatase and $\gamma$-Glutamyltransferase in Urine of Healthy Persons, Patients Suffering from Kidney Diseases and Patients with Kidney Transplants
}

\author{
By K.Jung, Monika Pergande, Carmen Reinholdt, B. Schulze, D. Scholz and V. Strobelt
}

\begin{abstract}
Abteilung für Experimentelle Organtransplantation und Klinik für Innere Medizin des Bereichs Medizin (Charité) der Humboldt-Universität zu Berlin und

Nierentransplantationszentrum der Urologischen Klinik im Städtischen Krankenhaus im Friedrichshain, Berlin, DDR
\end{abstract}

(Received February 2/April 9, 1984)

Summary: The catalytic activities of alanine aminopeptidase, alkaline phosphatase and $\gamma$-glutamyltransferase were determined in the soluble and particulate fractions of urine, after ultracentrifugation. In healthy adults the fractional catalytic activities in the supernatants were $0.53,0.56$ and 0.24 , respectively. Nearly the same proportions were found in children. In patients suffering from chronic kidney diseases there was a tendency for the proportion of catalytic activity in the soluble fraction to increase. However, the separation into the multiple forms gave no higher diagnostic reliability than the determination of total catalytic activity of the respective enzymes. The determination of multiple forms has no clinical significance in the detection of rejection episodes in renal transplant recipients.

Multiple Formen der Alaninaminopeptidase, alkalischen Phosphatase und y-Glutamyltransferase im Urin von gesunden Personen, Patienten mit Nierenerkrankungen und nierentransplantierten Patienten

Zusammenfassung: Im Urin gesunder Erwachsener betrug nach Ultrazentrifugation der Anteil der löslichen katalytischen Aktivität der Alaninaminopeptidase 0,53, der alkalischen Phosphatase 0,56 und der $\gamma$-Glutamyltransferase 0,24 der Gesamtaktivität. Ähnliche Verhältnisse wurden bei Kindern festgestellt. Patienten mit chronischen Nierenerkrankungen zeigten z.T. erhöhte lösliche katalytische Aktivitäten der Enzyme im Urin. Die diagnostische Aussagekraft durch die Bestimmung der multiplen Formen war jedoch geringer als durch Bestimmung der Gesamtaktivität der Enzyme. Bei nierentransplantierten Patienten ist die Bestimmung dieser multiplen Formen ohne Bedeutung für die Erfassung einer Rejektionskrise.

\section{Introduction}

The urinary enzymes alanine aminopeptidase $(\alpha-$ aminoacyl-peptide hydrolase (microsomal), EC 3.4.11.2), alkaline phosphatase (orthophosphoricmonoester phosphohydrolase (alkaline optimum), EC 3.1.3.1) and $\gamma$-glutamyltransferase ( $\gamma$-glutamyl)peptide: amino acid $\gamma$-glutamyltransferase, EC 2.3.2.2) can be separated by ultracentrifugation into particulate and soluble forms $(1-4)$. The diagnostic significance of these variants has not been tested. We have investigated the clinical significance of the two variants in healthy persons and patients suffering from chronic kidney diseases and with kidney transplants.

\section{Materials and Methods}

Separations of particulate and soluble forms were performed with urine specimens collected from 07.00 to 09.00 hours. Aliquots were centrifuged $(800 \mathrm{~g}, 10 \mathrm{~min})$ and then gel filtered on Sephadex $\mathrm{G} 50$ (fine) (5). The gel filtrate $(4 \mathrm{ml})$ was immediately ultracentrifuged $\left(105000 \mathrm{~g}, 1 \mathrm{~h} ; 4^{\circ} \mathrm{C}\right)$. Supernatant $(3 \mathrm{ml})$ was removed, representing fraction 1 . The remaining $1 \mathrm{ml}$ and the pellet together formed fraction 2 . The enzyme catalytic activities were measured in the gel filtrates and both fractions as described previously (4). The soluble enzyme catalytic activity fraction (S) was calculated as follows:

$S=\frac{4 \times \text { activity fraction 1 }}{3 \times \text { activity } \text { fraction } 1+\text { activity fraction } 2}$

We investigated 20 healthy aduits ( 10 women, 10 men; mean age: 35 years), 12 healthy children ( 7 girls, 5 boys; mean age: 2.5 years), 12 patients suffering from chronic pyelonephritis (8 wom- 
en, 4 men; mean age: 39 ycars; $162 \pm 137 \mu \mathrm{mol} / 1$ creatinine in scrum), 19 patients suffering from chronic glomerulonephritis $(2$ women, 17 men; mean age: 27 years; $137 \pm 164 \mu \mathrm{mol} / / \mathrm{creati}-$ nine) and two groups of renal transplant recipients. Eighteen renal transplant recipients (6 women, 12 men) were investigated on every working day after transplantation until the discharge from hospital and 13 renal transplant recipients (4 women, 9 men; mean age 41 years; $108 \pm 27 \mu \mathrm{mol} / \mathrm{l}$ creatinine) in the late period $(69.5 \pm 40.8$ months) after transplantation.

Statistical analyses were made with the t-test according to Student.

\section{Results and Discussion}

Table 1 lists the soluble catalytic activity fraction of the three urinary enzymes in the groups investigated. On the whole, our data for healthy persons correspond to the values reported recently $(1-3)$. A difference between the values of adults and children was found only for $\gamma$-glutamyltransferase, but this difference is negligible. A considerable part of the excreted catalytic activity consists of the particulate form. Unlike the respective serum enzymes (6), these enzyme complexes are components of normal urine. They result from the shedding of membrane fragments due to the normal turnover of the brushborder of proximal tubules (3). The soluble catalytic activity, however, results from the dissociation of the enzymes from membrane fragments in urine or directly from release from the cells (3). It can be assumed that the quantity of soluble catalytic activity has already been regulated intracellularly (7).
Under pathological conditions the soluble variant is excreted increasingly in the urine (tab. 1). The increase of soluble catalytic activity is different for the three enzymes. This increase applies to all three enzymes in patients in the early period after renal transplantation and occurs within the first week after transplantation (fig. 1). The values obtained 7 days after transplantation and at the time of discharge from hospital do not differ, and they are also unchanged by a rejection (tab. 1). At a later period after transplantation, however, the soluble catalytic activities of renal transplant recipients differ from those of healthy persons; and they differ greatly from the values of patients in the early period after transplantation $(\mathrm{p}<0.01)$.

The altered proportions of soluble forms can be an expression of increased release of soluble variants from the damaged cell or the increased synthesis in the regenerative phase (2). It is suggested that in patients suffering from chronic kidney diseases both processes proceed simultaneously. The temporal behaviour of soluble catalytic activities after renal transplantation, however, testifies more to the lastmentioned possibility in renal transplant recipients.

Since comparison of mean values hardly admits an assessment of the diagnostic evidence of tests, we reclassified our patients by means of the determined enzyme catalytic activities. Out of 31 patients suffering from chronic kidney diseases we found 21 patients who exhibited total alanine aminopeptidase

Tab. 1. Soluble catalytic activity of alanine aminopeptidase, alkaline phosphatase and $\gamma$-glutamyltransferase in urine of healthy persons and patients. Data are given as fraction of total catalytic activity (arithmetic mean $\pm S D$ ). Values for children and patients were compared with values for healthy adults. Renal transplant recipients in the "early period" (38 \pm 13 days) and in the "late period"' (69.5 \pm 40.8 months) after transplantation. Symbols: ${ }^{+} p<0.01$; $^{++} p<0.001$.

\begin{tabular}{|c|c|c|c|c|c|c|}
\hline \multirow[t]{3}{*}{ Groups } & \multicolumn{2}{|c|}{ Alanine aminopeptidase } & \multicolumn{2}{|c|}{ Alkaline phosphatase } & \multicolumn{2}{|c|}{$\gamma$-Glutamyltransferase } \\
\hline & $\begin{array}{l}\text { Total } \\
\text { activity }\end{array}$ & $\begin{array}{l}\text { Soluble activity } \\
\text { fraction }\end{array}$ & $\begin{array}{l}\text { Total } \\
\text { activity }\end{array}$ & $\begin{array}{l}\text { Soluble activity } \\
\text { fraction }\end{array}$ & $\begin{array}{l}\text { Total } \\
\text { activity }\end{array}$ & $\begin{array}{l}\text { Soluble activity } \\
\text { fraction }\end{array}$ \\
\hline & $\overline{\mathrm{x}}(\mathrm{U} / \mathrm{I})$ & & $\overline{\mathrm{X}}(\mathrm{U} / \mathrm{l})$ & & $\overline{\mathbf{x}}(\mathrm{U} / \mathrm{I})$ & \\
\hline
\end{tabular}

\section{Healthy persons}

Adults $(\mathrm{n}=20)$

Children $(n=12)$

Chronic glomerulonephritis ( $n=19$ )

Chronic pyelonephritis

$(\mathrm{n}=12)$

Renal transplant recipients

Early period $(n=13)$

Late period $(n=13)$

At rejection day $(n=6)$

$0.62 \pm 0.26$

$0.62 \pm 0.22$

$0.82 \pm 0.08^{++}$

$0.53 \pm 0.14$

$0.84 \pm 0.07^{++}$

9.2
9.9
23.7

\section{7}

8.7

$0.56 \pm 0.13$

$0.48 \pm 0.12$

18.3

$0.72 \pm 0.19^{+}$

42.2
$0.72 \pm 0.17$

41.9

$0.37 \pm 0.16^{+}$
$0.24 \pm 0.03$

$0.31 \pm 0.03^{++}$ 
catalytic activity beyond the range of $\bar{x}+2 S D$ of the control group and 22 patients with increased $\gamma$-glutamyltransferase and alkaline phosphatase, respective-

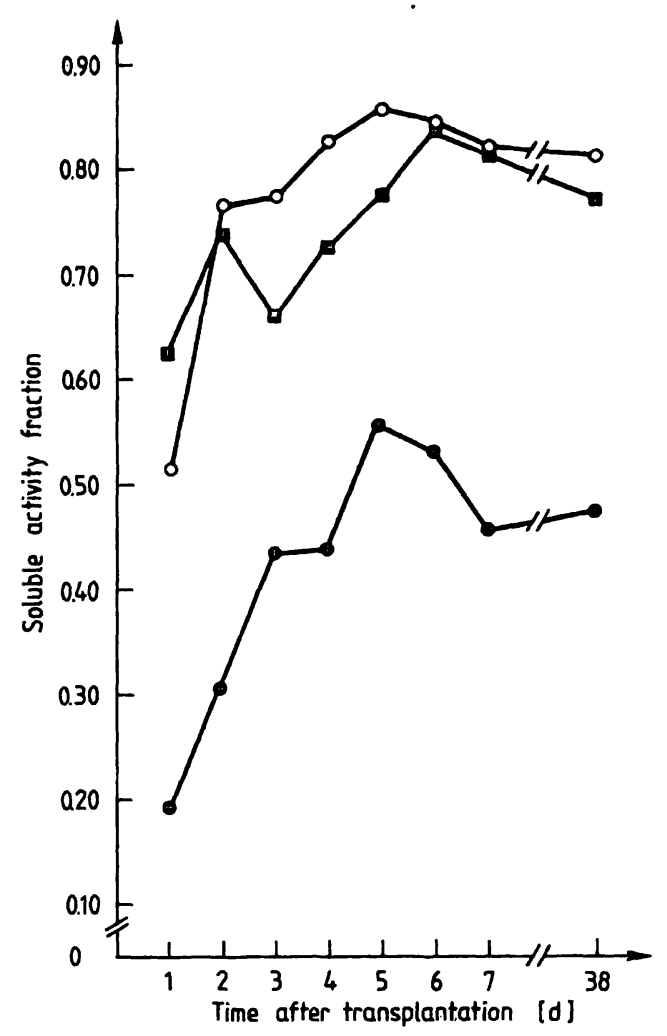

Fig. 1. Soluble catalytic activity fraction of alanine aminopeptidase (O-O), alkaline phosphatase ( $\square-\square)$ and $\gamma$-glutamyltransferase (O-O) in urine of renal transplant recipients without rejection episodes in the early period after transplantation.

Data are given as arithmetic means $(n=9-13)$. ly. Considering the respective values of absolute soluble catalytic activities and soluble catalytic activity fractions of the three enzymes, the number of patients with abnormal values were smaller in each case. However, 4 out of 10 patients having normal total alanine aminopeptidase and 3 out of 9 patients having normal alkaline phosphatase and $\gamma$-glutamyltransferase, respectively exhibited soluble catalytic activities clearly beyond the normal range. With respect to these patients, our study indicates that the separation into the multiple forms gives no higher diagnostic reliability than the determination of total catalytic activity. Only in isolated cases, can the evidence attained with total catalytic activity be improved by the determination of soluble enzyme forms.

In renal transplant recipients determinations of urinary enzymes have proved to be a reliable indicator in detecting rejection episodes (8). In 18 patients the soluble forms of the three enzymes were continuously determined after transplantation until discharge from hospital. Both during rejection episodes and in patients without rejection, catalytic activities were found which were above and below the reference interval. Separation of these enzymes seems to have no clinical significance for the detection of rejection episodes.

In summary, it can be concluded that the measurement of the multiple forms of these three urinary enzymes separated by ultracentrifugation has only limited clinical value.

\section{References}

1. Linder, M. \& Sudaka, P. (1982) Clin. Chim. Acta 118, 77-85.

2. Pfleiderer, G., Baier, M., Mondorf, A. M., Stefanesçu, T., Scherberich, J. E. \& Müller, H. (1980) Kidney Int. 17, 242249.

3. Rambabu, K., Jacob, R. T. \& Pattabiraman, T. N. (1981) Clin. Chim. Acta 109, 257-265.

4. Jung, K. \& Pergande, M. (1983) Clin. Chem. 29, 392-393.
5. Werner, M., Maruhn, D. \& Atoba, M. (1969) J. Chromatogr. 40, 254-263.

6. Crofton, P. M. \& Smith, A. F. (1981) Clin. Chem. 27, 860866.

7. Welbourne, T. C., Phifer, T., Thomas, M. \& Dass, P. D. (1983) Life Sci. 33, 1141-1147.

8. Vanderlinde, R. E. (1981) Ann. Clin. Lab. Sci. 11, 189-201.
Dr. sc. Klaus Jung

Abteilung für Experimentelle Organtransplantation des Bereichs Medizin (Charité) der Humboldt-Universität zu Berlin Leninallee 49 DDR-1017 Berlin 
